The undercarriage is of tricycle form so placed that the machine can land and stand with the cabin horizontal, which will increase the comfort of the passengers and facilitate loading up when on the ground. The wheels are retractable during flight. The cabin is air-tight, and conditioned air at groundlevel density is maintained when flying at altitudes. The machine is fitted with an automatic pilot, relieving the pilot of most of his physical work, and making him more analogous to the captain of a ship. The whole of the mechanical detail is controlled from the flight engineer's cabin, who has actually sixty-four dials on his instrument board, dealing with matters varying from engino and flying performance down to the condition of the air in the cabin. A new feature of this machine is an auxiliary wing that can be retracted when not required. It is shaped like the more familiar trailing edge flap, and thus can bo used as an air brake for reducing landing speeds as well as providing the extra surface for increasing the flying speed range. This additional surface allows for a wing loading of $25 \mathrm{lb}$. per square foot for taking off and landing, which is increased to $32 \mathrm{lb}$. per square foot while flying with it retracted. The estimated speeds of the machine are 275 m.p.h. maximum, and 220 m.p.h. cruising, and its air endurance with the full load of passengers will enable it to operate nonstop to any European capital. With a decreased pay load it will be capable of fast non-stop services on the Empire routes.

\section{Neanderthal Man in Italy}

Is more respects than one, the discovery of a skull of Neanderthal man in the Guttari cave at Monte Felice Circeo, about sixty miles south of Rome, is of unique significance for the study of the chronology and distribution of Mousterian man in Europe of the palæolithic period. Owing to conditions affecting tho use of the cave by man, it is possible to fix the date of occupation within tolerably accurate limits, while the sealing of the cave in Mousterian times which brought that occupation to a close, has not only preserved the evidence of Neanderthal man and his domestic economy intact but also saved it from the superposition of the debris of subsequent intrusionsconditions unique in caves of Mousterian occupation. The skull, now the third of the type known from Italy, was found on February 25, 1939, by Dr. A. C. Blane of the University of Pisa, who with the Abbé Breuil, discovered the secund of the Italian Neander. thal skulls. Dr. Blane had already examined thirtyone caves at Monte Circeo and found in them evidence of both the Mousterian and Aurignacian cultures, but the present find was made in a cave which had been discovered on the previous day only by its owner, S. A. Guttari.

Tre skull lay on the floor of an inner chamber of the cave among stones which appear to have been laid in a circle around it, while underneath it were bones of Equus, Bos, Cervus and Sus, some of which had been intentionally flaked. The floor of the whole cave was covered with fossilized mammalian bones, antlers and skulls, including, in addition to those mentioned, hyæna and others, while elephant bones were found in a pool. All belonged to a warm climatic phase. This Neanderthal skull is the most perfect yet known, and in size approaches that of La Chapelle aux Saints. A fracturo of the right temporal region points to a violent death; and the base of the sliull has been opened extensively and the greater portion of the occipital foramen destroyed. The date of occupation is fixed by relation to the oscillation of sea-level at somewhere between 130,000 and 70,000 years ago ; and Sir Arthur Keith, who contributed a prefatory note to an account, with illustrations, of Dr. Blanc's discovery in the Illustrated London News of July 5, regards these relics of Neanderthal man as contemporary with the lowest level of the Grotte des Enfants, Mentone.

\section{Recent Additions to the British Museum (Bloomsbury)}

Sorre striking examples of West African art were among the more important of the recent additions to the ethnographical collections of the British Museum, which were reported at the meeting of the Trustees on July 8. Of these one was a gift of the National Art Collections Fund-a cast bronze head which was excavated at Ife, the religious centre of the Ioruba people, and is said to represent Olokun, the Yoruba deity of the sea. Discovered in 1938, it is in good condition, and shows traces of red paint on the head-dress. Probably it belongs to the fifteenth or sixteenth century, though the date is uncertain. Its modelling is of a quality unique among the artistic productions of negro Africa, and bears comparison with the finer sculptures of civilized art. The second example of African art is a carved ivory tusk from Benin, which bears figures of fish and animals, symbolizing the king in his supernatural aspects. There is a receptacle for magical 'medicine' at the larger end. No similar example is known. The gift to the Department of Manuscripts of the diaries of Robert Needham Cust, an Indian civil servant well known as an orientalist among scholars of the nineteenth century, will be welcomed by all who are interested in the history of Indian and oriental studies. The diaries were presented by his son, Mr. R. H. H. Cust.

\section{Utilization of Coal}

The British Coal Utilization Research Association held its first annual meeting in London on June 28, when Sir Evan Williams, the president, gave an account of its first year's work, which has been largely concerned with the erection and organization of its research station in Fulham. It has been a subject of reproach that the coal industry has been largely indifferent to promoting efficiency in the utilization of coal. They now foresee, the president said, that the future will call for fuels of accurately controlled characteristics; the development of these is being investigated. The programmo of research in. cludes work on pulverized fuel firing which, it is believed, will play an increasingly important part in industry, and also on combustion in the fuel bed. 